\title{
Erratum to: Demography and movement patterns of leopard sharks (Triakis semifasciata) aggregating near the head of a submarine canyon along the open coast of southern California, USA
}

\author{
A. P. Nosal • D. C. Cartamil • J. W. Long • \\ M. Lührmann • N. C. Wegner • J. B. Graham
}

Published online: 16 March 2013

(C) Springer Science+Business Media Dordrecht 2013

\section{Erratum to: Environ Biol Fish \\ DOI 10.1007/s10641-012-0083-5}

The authors wish to correct two errors discovered in the original manuscript. First, in the legend of Fig. 3, "50 \% KUD" should read "95\% KUD" and "95\% KUD" should read "50 \% KUD." Second, in the legend of Fig. 6, "50 \% KUD $\mathrm{KOT}_{\text {" }}$ should read "95\% KUD Tот" " and "95 \% KUD

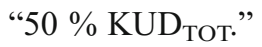

The online version of the original article can be found at http:// dx.doi.org/10.1007/s10641-012-0083-5.

\author{
A. P. Nosal $(\bowtie)$ \\ Center for Marine Biodiversity and Conservation, \\ Scripps Institution of Oceanography, \\ University of California - San Diego, \\ La Jolla, CA 92037, USA \\ e-mail: anosal@ucsd.edu
}

D. C. Cartamil • N. C. Wegner · J. B. Graham

Center for Marine Biotechnology and Biomedicine,

Scripps Institution of Oceanography,

University of California - San Diego,

La Jolla, CA 92037, USA
J. W. Long

St. Petersburg Coastal and Marine Science Center,

United States Geological Survey,

St. Petersburg, FL 33701, USA

M. Lührmann

Institute of Biological Sciences, University of Rostock, 18059 Rostock, Germany

N. C. Wegner

Fisheries Resource Division, Southwest Fisheries Science Center, National Marine Fisheries Service,

National Oceanic and Atmospheric Administration,

La Jolla, CA 92037, USA 